\title{
Isotopic study on Dokriani Bamak glacier, central Himalaya: implications for climatic changes and ice dynamics
}

\author{
Vasant NIJAmpURKaR,${ }^{1}$ Kameswara RAO,${ }^{1}$ Manmohan SARIN,${ }^{1}$ Joseph GERGAN ${ }^{2}$ \\ ${ }^{1}$ Physical Research Laboratory, Navrangpura, Ahmedabad 380 009, India \\ E-mail:sarin@pr1.ernet.in \\ ${ }^{2}$ Wadia Institute of Himalayan Geology, Dehradun 248 001, India
}

\begin{abstract}
Measurements of natural and artificial radioisotopes $\left({ }^{32} \mathrm{Si},{ }^{210} \mathrm{~Pb}\right.$ and $\left.{ }^{137} \mathrm{Cs}\right)$ and oxygen isotopes $\left(\delta^{18} \mathrm{O}\right)$ have been carried out on surface snow and ice, shallow snow pits and an ice core collected from Dokriani Bamak glacier, central Himalaya, to study the dynamics of glacier ice and short-term climatic changes. Based on the ${ }^{32} \mathrm{Si}$ and ${ }^{210} \mathrm{~Pb}$ activities in the meltwaters, the age of the snout ice is 400 years and the flow rate of ice along the glacier length is $\sim 14 \mathrm{~m} \mathrm{a}^{-1}$. The specific activity of ${ }^{137} \mathrm{Cs}$, corresponding to 1963 fallout, in the surface ice at the equilibrium line yields a flow rate of $32 \mathrm{~m} \mathrm{a}^{-1}$, a factor of two higher than that derived for the snout ice. The depth variation of ${ }^{137} \mathrm{Cs}$ concentration in a shallow ice core yields a mean accumulation rate of $0.43 \mathrm{~m} \mathrm{a}^{-1}$ for the glacier ice over the past decade. The $\delta^{18} \mathrm{O}$ of snout ice $(-13.4 \%)$ is significantly depleted compared to the average value of $-9.2 \%$ in the shallow ice core, indicating that cooler climatic conditions prevailed around $\mathrm{AD} 1600$. Based on the oxygen isotopic ratios in the shallow pits, an "altitude effect" of $0.9 \%$ per $100 \mathrm{~m}$ in $\delta^{18} \mathrm{O}$ variation is documented for this glacier.
\end{abstract}

\section{INTRODUGTION}

Glaciers and ice sheets play an important role in the understanding of present and past environmental changes, as well as providing information on the areal deposition patterns of nuclear and volcanic events. Polar glaciers are known to preserve these records systematically for many thousands of years due to the minimal melting of ice in Arctic and Antarctic regions (Delmas and others, 1982; Von Gunten and others, 1983; Jouzel and others, 1987). In contrast, temperate glaciers (located in high altitudes) hold potential records of environmental changes covering time-scales of a few centuries (Thompson and others, 1997). In this context, radioactive isotopes serve as excellent time markers, while stable isotopes are sensitive indicators of climatic change. The natural radioisotopes of both short and long half-lives $\left({ }^{3} \mathrm{H}=12.3\right.$ years; ${ }^{210} \mathrm{~Pb}=22.3$ years; ${ }^{32} \mathrm{Si}=178$ years (as revised by Nijampurkar and others, 1998); ${ }^{14} \mathrm{C}=5730$ years) and the artificial radioisotope ${ }^{137} \mathrm{Cs}$ (half-life $=30$ years) have been used to derive the accumulation rates and ages of young and older ice in polar and temperate regions. The stable-isotope composition of snow $\left(\delta^{18} \mathrm{O}\right.$ and $\left.\delta \mathrm{D}\right)$ deposited in the polar and mid-latitude regions depends mainly on the air temperature and sources of moisture (Nijampurkar and Bhandari, 1984; Peel and others, 1988). The $\delta^{18} \mathrm{O}$ and $\delta \mathrm{D}$ measurements, therefore, can be used to understand the depositional history of ice, past climatic variations, sublimation and homogenization processes occurring in the upper layers of glacier ice.

During the past 30 years, several studies have been carried out in polar and temperate regions, particularly Antarctic, Arctic and Alpine regions, using radioactive and stable isotopes (Dansgaard and others, 1969; Jouzel and others, 1987). Studies from the Indian and Nepal Himalaya are relatively sparse (Yasunari 1976; Grabczak and others, 1983; Nijampurkar and Bhandari, 1984; Mayewski and others, 1986; Wake, 1989; Nijampurkar and Rao, 1993). Recent studies based on $\delta^{18} \mathrm{O}$ in snow/ice and ice core from the Tibetan (Xizang) Himalaya have addressed the seasonal relationship between $\delta^{18} \mathrm{O}$ in snow/ice and air temperature and moisture sources (Aizen and others, 1996; Yao and others, 1996; Thompson and others, 1997). Yao and others (1996) demonstrated that the $\delta^{18} \mathrm{O}-T$ relationship has a positive slope over the northern part of the Tibetan Plateau and suggest that the slope "inverts" over a narrow band between the Himalaya and the central plateau to the north.

The climate of the glaciated central Himalayan region is influenced by precipitation during the summer monsoon which develops over the Asian countries. Over India, the monsoonal rains begin by mid-June. The southwest monsoon also plays an important role during the ablation period of Himalayan glaciers. Precipitation in the form of snow occurs only during October to March, when the primary source of moisture is related to the winter monsoon and western disturbances. The accumulation is maximum when the snowline recedes to about $1500 \mathrm{~m}$ in the western Himalaya and to about $3000 \mathrm{~m}$ in the eastern Himalaya.

The main objectives of this study are: (i) to obtain information on the ice dynamics and snow-accumulation rates of Dokriani Bamak glacier, and (ii) to decipher the relationship, if any, between the annual mean $\delta^{18} \mathrm{O}$ content in surface snow and elevation with respect to glacier orientation. The isotopic data on snow/ice and shallow ice core, thus collected, are evaluated in terms of their implications for shortterm climatic changes and the depositional history of the glacier ice. 


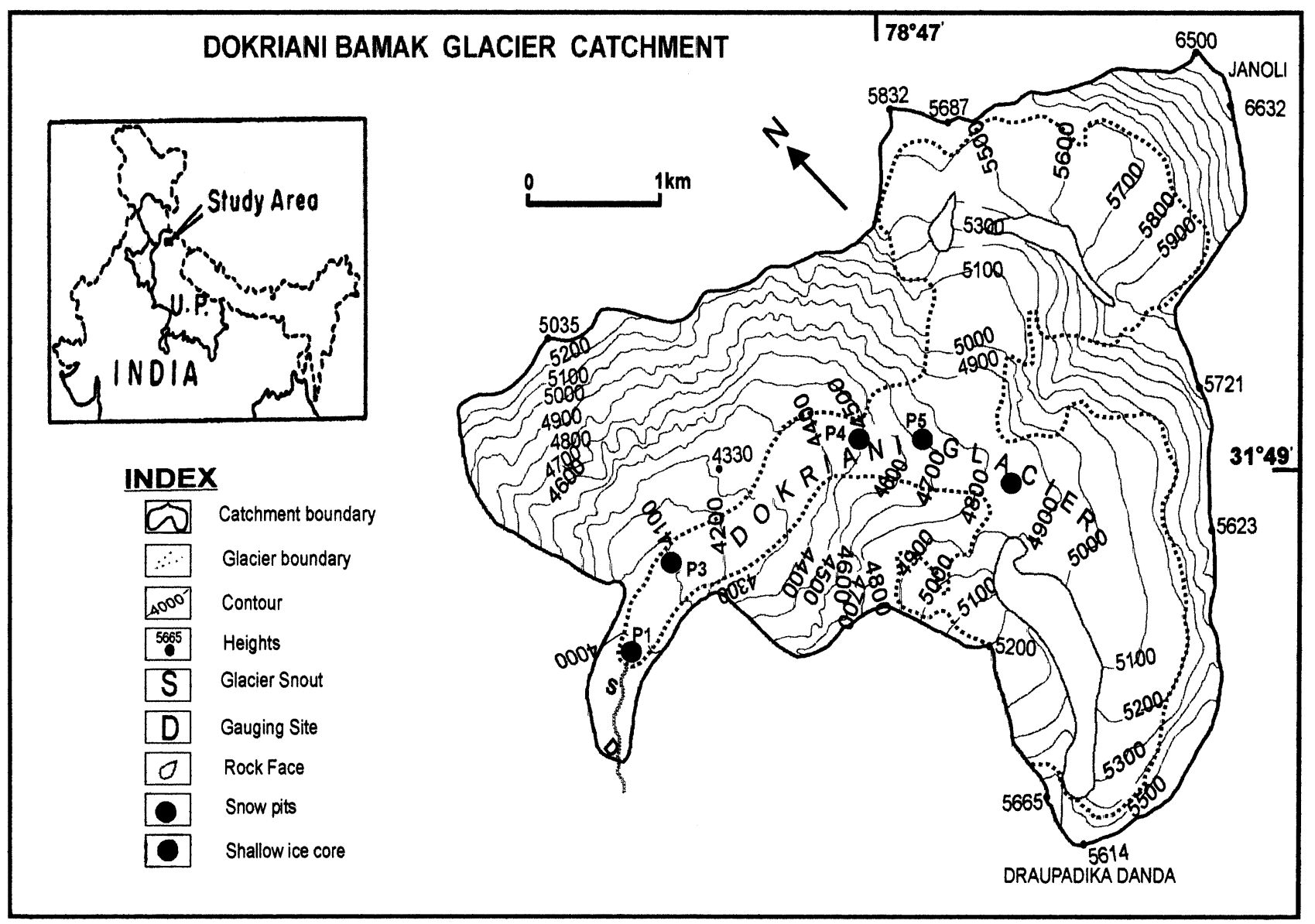

Fig. 1. Contour map of DB glacier. The location of snow and ice samples and the shallow ice core collected along the central flowline of the glacier are also indicated ( see Table 2).

\section{LOGATION}

Dokriani Bamak (DB) glacier, located at $31^{\circ} 49^{\prime} \mathrm{N}, 78^{\circ} 47^{\prime} \mathrm{E}$ and at an altitude of $3900-5000 \mathrm{~m}$, is a well-developed valley glacier of the Gangotri group in the central Himalaya. It lies southwest of Gangotri glacier (Fig. 1). DB glacier is $6 \mathrm{~km}$ long and its width varies from $0.86 \mathrm{~km}$ near the snout to $1.5 \mathrm{~km}$ in the accumulation zone. Within its catchment area of $15.2 \mathrm{~km}^{2}$, $9.8 \mathrm{~km}^{2}$ is covered with ice and $4.1 \mathrm{~km}^{2}$ with permanent snowfields. DB glacier is formed by two cirque glaciers: one on the northern slopes of Draupadi ka Danda (5614 m a.s.l.) and the other on the southwestern slopes of Janoli (6632 m a.s.l.) (Fig. 1). It then flows from the accumulation zone with a gradient of $12^{\circ}$. It terminates at an altitude of $3882 \mathrm{~m}$ and flows between the eroded lateral moraines formed during the past glacial periods. Lateral moraines are prominent glacial features of Din Gad Valley (Fig. 1). Three-quarters of the ablation zone of the glacier is overlain by a thick cover of supraglacial debris. Marginal and transverse crevasses are well developed in the ablation zone, particularly in the altitude range 4200-4300 m; longitudinal and splaying crevasses are developed on the northeast flank of the icefall. Avalanches occur very frequently in the accumulation zone of the glacier. The geomorphology of the glacier is discussed in detail elsewhere (Gergan and Dhobal, 1996). DB glacier is one of the few glaciers in the Bhagirathi basin that is easily accessible throughout the year. Located on the southern slopes of the Himalaya, it faces southward with respect to the Himalaya. The major source of moisture is the rainfall that occurs during the summer monsoon (June-September), passing over the glacier from west to east and giving an average precipitation of 1000-1200 mm below the equilibrium line. The second phase of precipitation occurs as snowfall from October to March (at times it extends to April), when western disturbances move eastward over northern India.

Recession of glaciers is observed worldwide, and Himalayan glaciers are no exception. DB glacier receded at an average rate of $17.5 \mathrm{~m} \mathrm{a}^{-1}$ during the period 1990-95. Massbalance studies carried out on the glacier during the sampling period 1992-95 show a negative trend. The equilibrium-line altitude calculated from mass-balance data shows an increase in height in successive years, which indicates that the accumulation-area ratio of $\mathrm{DB}$ glacier decreased from 0.68 to 0.62 during 1992-95 (Gergan and Dhobal, 1996). A rise in the atmospheric temperature is indicated by an increase in the height of the equilibrium line.

\section{SAMPLE COLLEGTION AND ANALYTICAL TEGHNIQUES}

\subsection{Sample collection}

The snow and surface ice samples were collected at altitudes of $3800-4900 \mathrm{~m}$ along the central flowline of the glacier during 1992-94. The snow samples from four different pits (Fig. 1) were collected during May-June 1994 at varying altitudes and depths along the central axis of the glacier flow. A $6 \mathrm{~m}$ long ice core was raised during October-November 1993, at an altitude of $4863 \mathrm{~m}$ in the accumulation zone, and was subsampled at an interval of $20 \mathrm{~cm}$. During the 1992 expedition, large quantities $(\sim 1000 \mathrm{~kg})$ of surface snout ice were collected and processed for determination of ${ }^{32} \mathrm{Si}$ activity and dating of the snout ice. The chemical procedures adopted in the field as well as in the laboratory for the extraction, 
Table 1. DB glacier: snout-ice ages

\begin{tabular}{ccccc}
\hline Isotope & $\begin{array}{c}\text { Samplesize } \\
\mathrm{kg}\end{array}$ & Specificactivity $^{*}$ & $\begin{array}{c}\text { Apparent age }^{\dagger} \\
\text { years }\end{array}$ & $\begin{array}{c}\text { Corrected age }^{*} \\
\text { years }\end{array}$ \\
\hline${ }^{{ }^{32} \mathrm{Si}}$ & 850 & $3.7 \pm 0.5 \mu \mathrm{Bq} \mathrm{kg}^{-1}$ & 297 & 400 \\
${ }^{210} \mathrm{~Pb}$ & 14 & $13.2 \pm 1.3 \mathrm{mBq} \mathrm{kg}^{-1}$ & 75 & - \\
\hline
\end{tabular}

* Specific activities are computed from the measured count rates and counter efficiency parameters.

$\dagger$ Apparent age is derived from the radioactive decay equation as used by Nijampurkar and others (1982).

* Corrected age is calculated by correcting ${ }^{32} \mathrm{Si}$ activity for the contribution from fresh water based on the measured ${ }^{210} \mathrm{~Pb}$ activity in the snout ice (Nijampurkar and others, 1982).

purification and estimation of ${ }^{32} \mathrm{Si}$ and ${ }^{137} \mathrm{Cs}$ are described in our earlier papers (Nijampurkar and others, 1982; Nijampurkar and Rao, 1992); ${ }^{210} \mathrm{~Pb}$ was assayed by alpha spectrometry (Sarin and others, 1992).

\subsection{Analytical techniques}

\section{${ }^{32}$ Si analysis}

About $1000 \mathrm{~kg}$ of meltwater was collected from snout ice in plastic drums and spiked with $\mathrm{Na}_{2} \mathrm{SiO}_{3}$ and $\mathrm{FeCl}_{3}$ solutions. After equilibration, silica was co-precipitated along with $\mathrm{Fe}(\mathrm{OH})_{3}$ at a $\mathrm{pH}$ of $\sim 8$. In the laboratory, silica (along with ${ }^{32} \mathrm{Si}$ ) was separated from $\mathrm{Fe}(\mathrm{OH})_{3}$ and allowed to equilibrate with its daughter isotope, ${ }^{32} \mathrm{P}\left(t_{1 / 2}=14.3\right.$ days $)$. After $3-4$ months, ${ }^{32} \mathrm{P}$ was recovered as $\mathrm{Mg}_{2} \mathrm{P}_{2} \mathrm{O}_{7}$ and its activity was assayed on a low-background Geiger-Müller counter operated in anti-coincidence with a $\mathrm{NaI}(\mathrm{Tl})$ detector (Nijampurkar and others, 1982). The counting system had an efficiency of $27 \%$. The in situ ${ }^{32} \mathrm{Si}$ concentration in the snout ice was ascertained from the measured ${ }^{32} \mathrm{P}$ activity.

\section{${ }^{137}$ Cs analysis}

Samples of snow, surface ice and those from the shallow ice core were filtered to remove suspended dust, if any, and acidified with $8 \mathrm{M} \mathrm{HNO}_{3}$. The filtrate was evaporated to dryness, and the residue was counted on a high-resolution, low-background HPGe well detector for assessing ${ }^{137} \mathrm{Cs}$ activity under the $661.5 \mathrm{keV}$ photopeak.

\section{$\delta^{18} \mathrm{O}$ measurements}

About $10 \mathrm{~g}$ samples of meltwaters from the snow/ice, pits and shallow ice-core samples were collected in airtight plastic bottles, transported to the laboratory and kept frozen until analysis. Oxygen isotope analysis was carried out using an auto-mass spectrometer at the Glaciology Laboratory of the Niels Bohr Institute, Copenhagen, Denmark.

\section{RESULTS AND DISGUSSION}

The results of the isotope analysis on snow/ice, pits and shallow ice-core samples from DB glacier are given in Tables 1-3 and Figures 2-6, and are discussed in relation to glacier ice flow and accumulation rates and short-term climatic variations.

\subsection{Radioisotopic studies for ice dynamics}

Dating of snout ice of the glacier by ${ }^{32}$ Si and ${ }^{210} \mathrm{~Pb}$

The specific activities of ${ }^{32} \mathrm{Si}$ and ${ }^{210} \mathrm{~Pb}$ in the snout-ice samples collected during August 1992 are calculated to be $3.7 \pm 0.5 \mu \mathrm{Bq} \mathrm{kg}^{-1}$ and $13.2 \pm 1.3 \mathrm{mBq} \mathrm{kg}^{-1}$, respectively (Table
Table 2. Specific activity of ${ }^{137} \mathrm{Cs}$ in snow/ice samples collected at different altitudes on DB glacier

\begin{tabular}{|c|c|c|c|c|}
\hline Sample code & Sample & $\begin{array}{l}\text { Altitude } \\
\mathrm{m}\end{array}$ & $\begin{array}{l}\text { Volume } \\
\mathrm{kg}\end{array}$ & $\begin{array}{c}\text { Specific activity }{ }^{137} \text { Cs } \\
\mathrm{mBq} \mathrm{kg}^{-1}\end{array}$ \\
\hline \multicolumn{5}{|c|}{ A. Snow samples collected after the first snowfall, 6 November 1993 (4 cm snowfall) } \\
\hline S-93-53 & Snow & 4320 & 1.16 & $<1.5$ \\
\hline S-93-52 & Snow & 4200 & 1.00 & $<1.5$ \\
\hline S-93-51 & Snow & 3960 & 0.48 & $3.8 \pm 2.5$ \\
\hline \multicolumn{5}{|c|}{$\begin{array}{l}\text { B. Snow samples collected after the second snowfall during 7-8 November } 1993 \text { (20 cr } \\
\text { snowfall) }\end{array}$} \\
\hline S-93-54 & Snow & 4380 & 0.86 & $<1.5$ \\
\hline S-93-55 & Snow & 4295 & 1.19 & $<1.5$ \\
\hline S-93-56 & Snow & 4096 & 0.46 & $<1.5$ \\
\hline \multicolumn{5}{|c|}{ C. Surface ice samples collected at different altitudes } \\
\hline S-93-41 & Surface ice & 4380 & 0.62 & $22 \pm 3.8$ \\
\hline S-93-43 & Surface ice & 4295 & 0.56 & $<1.5$ \\
\hline S-93-44 & Surface ice & 4200 & 0.64 & $<1.5$ \\
\hline
\end{tabular}

1). Using a two-component box model (Nijampurkar and others, 1982), the corrected value of ${ }^{32} \mathrm{Si}$ activity in the snout ice is calculated to be $2.5 \mu \mathrm{Bq} \mathrm{kg}^{-1}$. Using this value and assuming the average ${ }^{32} \mathrm{Si}$ concentration of the snowfall in the Himalayan region to be $11.7 \mu \mathrm{Bq} \mathrm{kg}^{-1}$, a radiometric age of 400 years is obtained for the snout ice of DB glacier. The basic assumption made in the ${ }^{32} \mathrm{Si}$ dating method is that the production rate of ${ }^{32} \mathrm{Si}$, as well as its atmospheric fallout over the Himalayan region, has remained constant over the past few centuries. Based on a radiometric age of 400 years for the snout ice and a glacier length of $6 \mathrm{~km}$, the average flow rate of ice over the last four centuries is estimated to be $14 \mathrm{~m} \mathrm{a}^{-1}$. The ${ }^{32} \mathrm{Si}$ fallout concentration in snow, $11.7 \mu \mathrm{Bq} \mathrm{kg}^{-1}$, is an average value based on experimental data from two different glaciers, Nehnar in Kashmir, and Changme-Khangfu in Sikkim, which range between 5 and $16.7 \mu \mathrm{Bq} \mathrm{kg}^{-1}$ (Nijampurkar and others, 1982). A $10 \%$ change in the fallout concentration would change the snout-ice age by $\sim 7 \%$.

\section{Accumulation rates and surface flow rates}

The specific activities of ${ }^{137} \mathrm{Cs}$ in snow and surface ice samples collected during 1993 are given in Table 2. The concentrations of ${ }^{137} \mathrm{Cs}$ in snow samples at different altitudes are generally $<1.5 \mathrm{mBq} \mathrm{kg}^{-1}$. These activities represent the background level of ${ }^{137} \mathrm{Cs}$ concentration, as there was no significant emission of artificial radioactivity during the period of sample collection. However, the ${ }^{137} \mathrm{Cs}$ activity measured in the surface ice collected at $4380 \mathrm{~m}(\sim 500 \mathrm{~m}$ below the equilibrium line) is $22 \pm 3.8 \mathrm{mBq} \mathrm{kg}^{-1}$. The enhanced activity of ${ }^{137} \mathrm{Cs}$ is attributed to its peak fallout resulting from nuclear bomb tests during the early 1960s. Such an observation suggests that the snow deposited during 1963-64 in the accumulation zone ( $\sim 500 \mathrm{~m}$ above the equilibrium line) could have travelled all along the glacier flowline and emerged at $4380 \mathrm{~m}$ altitude after nearly 30 years, traversing a total distance of $\sim 1000 \mathrm{~m}$. This linear movement allows us to estimate a glacier ice-flow rate of about $32 \mathrm{ma}^{-1}$ near the equilibrium line, which is higher than the average flow rate of ice (14 $\mathrm{m} \mathrm{a}^{-1}$ as determined from snout age) all along the glacier. It could be argued that ${ }^{137} \mathrm{Cs}$ activity in the surface ice at $4380 \mathrm{~m}$ is not related to 1963 fallout and instead is associated with the Chernobyl accident in April 1986. However, the ${ }^{137} \mathrm{Cs}$ activity arising from the former event is further supported by the measured ${ }^{210} \mathrm{~Pb}$ activity of $35 \mathrm{mBq} \mathrm{kg}^{-1}$ in the same sample. The constant fallout activity of ${ }^{210} \mathrm{~Pb}$ in the 
${ }^{137}$ Cs activity $\left(\mathrm{mBq} \mathrm{kg}^{-1}\right)$

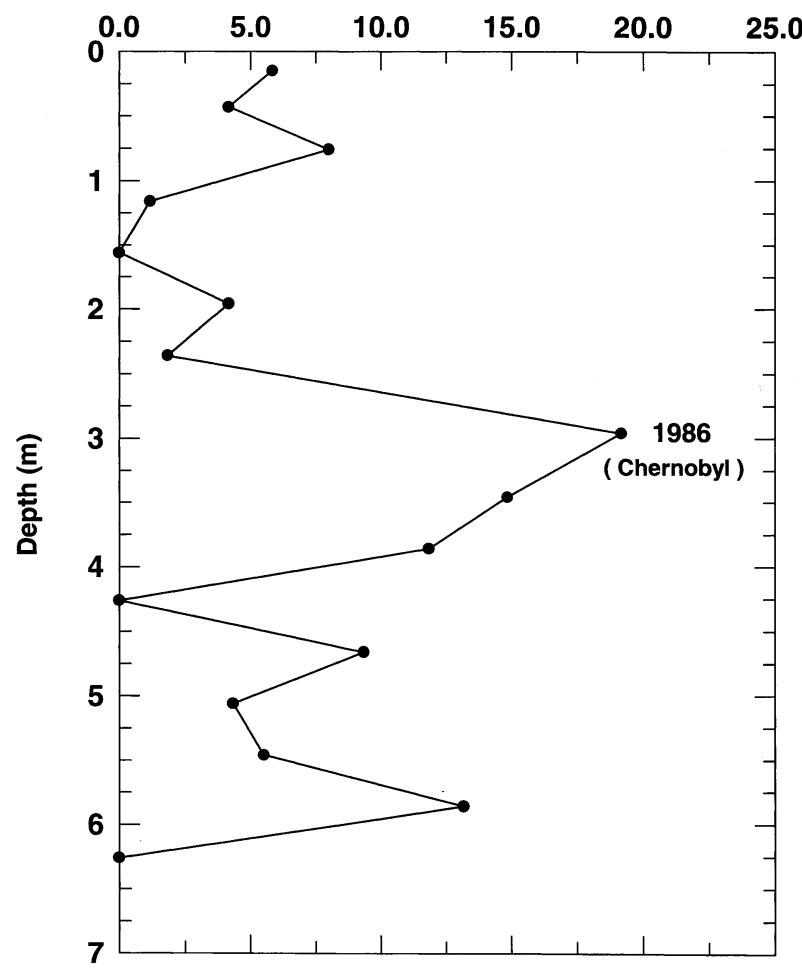

Fig. 2. The depth profile of ${ }^{137} \mathrm{Cs}$ specific activity $\left(\mathrm{mBq} \mathrm{kg}^{-1}\right)$ in a $6 \mathrm{~m}$ ice core collected from the accumulation zone of the glacier. The peak value at $\sim 3 \mathrm{~m}$ depth is attributed to the deposition of Chernobyl fallout in 1986

Himalayan glacier is $\sim 100 \mathrm{mBq} \mathrm{kg}^{-1}$ (Nijampurkar and others, 1982). This buried activity after a time-span of 30 years could correspond to $\sim 38 \mathrm{mBq} \mathrm{kg}^{-1}$, quite similar to that observed in the surface ice at $4380 \mathrm{~m}$. Thus, the flow rate of ice as deduced by us is quite representative near the equilibrium line. In Table 3, the snout-ice ages and time-averaged flow rates of the surface ice of some temperate Himalayan glaciers are compared (Nijampurkar and Rao, 1993). The snout ages vary from 160 to 840 years, whereas the ice-flow rates vary from 4 to $23 \mathrm{~m} \mathrm{a}^{-1}$.

The depth profile of ${ }^{137} \mathrm{Cs}$ specific activity in a $6 \mathrm{~m}$ ice core (raised at $4863 \mathrm{~m}$ in the accumulaton zone) shows a maximum value of $19.2 \mathrm{mBq} \mathrm{kg}^{-1}$ at $\sim 3 \mathrm{~m}$ depth (Fig. 2) compared to an average value of $3.3 \pm 2 \mathrm{mBq} \mathrm{kg}^{-1}$ up to $2.5 \mathrm{~m}$ depth and

Table 3. Physical characteristics of the Himalayan glaciers, snout ages and ice-flow rates

\begin{tabular}{|c|c|c|c|c|c|}
\hline \multirow[t]{2}{*}{ Glacier } & \multirow[t]{2}{*}{ Location } & Altitude & $\begin{array}{c}\text { Glacier } \\
\text { length }\end{array}$ & \multicolumn{2}{|c|}{ Snout Ice-flow } \\
\hline & & m a.s.l. & $\mathrm{km}$ & years & $\mathrm{ma}^{-1}$ \\
\hline Nehnar & $34^{\circ} 09^{\prime} \mathrm{N}, 75^{\circ} 30^{\prime} \mathrm{E}$ & $3920-4925$ & 3.4 & 840 & 4 \\
\hline Chhota Shigri & $32^{\circ} 15^{\prime} \mathrm{N}, 77^{\circ} 31^{\prime} \mathrm{E}$ & $4050-5000$ & 9.0 & 310 & 23 \\
\hline Dokriani Bamak & $31^{\circ} 49^{\prime} \mathrm{N}, 78^{\circ} 47^{\prime} \mathrm{E}$ & $3900-5000$ & 6.0 & 400 & 14 \\
\hline Gara & $31^{\circ} 30^{\prime} \mathrm{N}, 78^{\circ} 26^{\prime} \mathrm{E}$ & $4710-5600$ & 6.0 & 355 & 10 \\
\hline Gorgarang & $31^{\circ} 26^{\prime} \mathrm{N}, 78^{\circ} 24^{\prime} \mathrm{E}$ & $4765-5360$ & 3.5 & 160 & 18 \\
\hline Changme Khangpu & $27^{\circ} 58^{\prime} \mathrm{N}, 88^{\circ} 42^{\prime} \mathrm{E}$ & 5800 & 5.8 & 185 & 22 \\
\hline
\end{tabular}

\footnotetext{
* Snout-ice ages are calculated using a revised half-life of ${ }^{32} \mathrm{Si}$ as 178 years (Nijampurkar and others 1998) and an atmospheric fallout value of ${ }^{32} \mathrm{Si}$ as $11.7 \mu \mathrm{Bq} \mathrm{kg}^{-1}$.
}

Note: All data from Nijampurkar and Rao (1993) except DB glacier (this study).

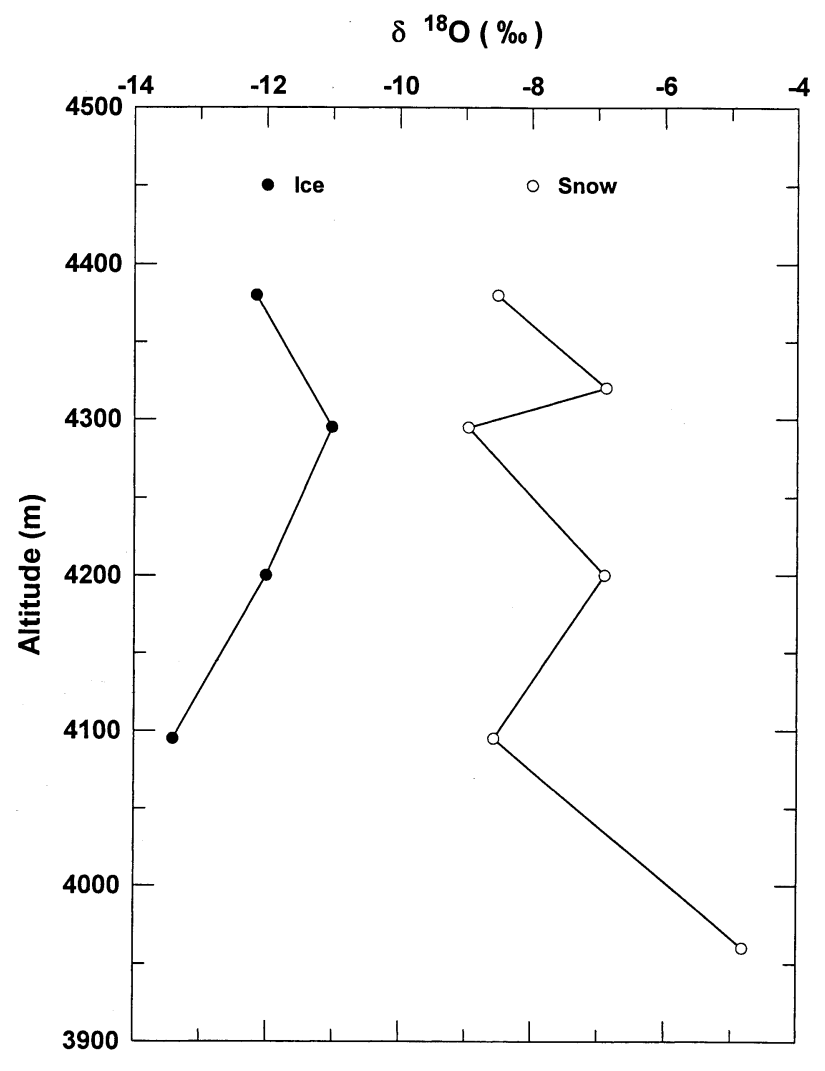

Fig. 3.Variation of $\delta^{18} O$ in fresh snow and ice samples collected during 1993 from different altitudes along the central flowline of the glacier.

of $5 \pm 3 \mathrm{mBq} \mathrm{kg}^{-1}$ at $4-6.25 \mathrm{~m}$ depth. The maximum activity is higher by a factor of 4 than the average value in snow samples above and below $3 \mathrm{~m}$ depth. This episode of enhanced ${ }^{137} \mathrm{Cs}$ activity in the ice core is attributed to Chernobyl fallout, similar to that observed on Chhota Shigri glacier (Nijampurkar and Rao, 1990). Using this activity as a time marker, the accumulation rate of ice at $4863 \mathrm{~m}$ in the accumulation zone of DB glacier is estimated to be $0.43 \mathrm{~m} \mathrm{a}^{-1}$, which is comparable with that observed on neighbouring glaciers in the central Himalaya.

\section{2. $\delta^{18} \mathrm{O}$ concentrations in snow, pits, surface ice and a shallow ice core}

\section{$\delta^{18} \mathrm{O}$ concentrations in snow and ice}

The results of the analysis of the fresh snow and surface ice samples collected at different altitudes (in both the accumulation and ablation zones of the glacier) are shown in Figure 3 . The $\delta^{18} \mathrm{O}$ in snow samples varied from $-5 \%$ to $-9 \%$; however, there is no systematic variation of $\delta^{18} \mathrm{O}$ with increasing altitude, as these samples represent only a single snowfall event and not the annual precipitation. These oxygen isotope ratios are similar to those reported in our earlier studies on Himalayan glaciers (Nijampurkar and Bhandari, 1984; Nijampurkar and Rao, 1992). The $\delta^{18} \mathrm{O}$ values of surface ice samples at different altitudes range from $-11 \%$ to $-13.4 \%$. The $\delta^{18} \mathrm{O}$ value of snout ice is $-13.4 \%$, the most depleted oxygen isotope ratio on the entire glacier. Comparison with the observed mean value of $-9.2 \%$ in a $6 \mathrm{~m}$ ice core from $4863 \mathrm{~m}$ elevation suggests that the depleted value of $\delta^{18} \mathrm{O}$ in snout ice $(-13.4 \%$ ) could be associated with the cooler climatic conditions prevailing a few centuries ago during the Little Ice Age (LIA). 

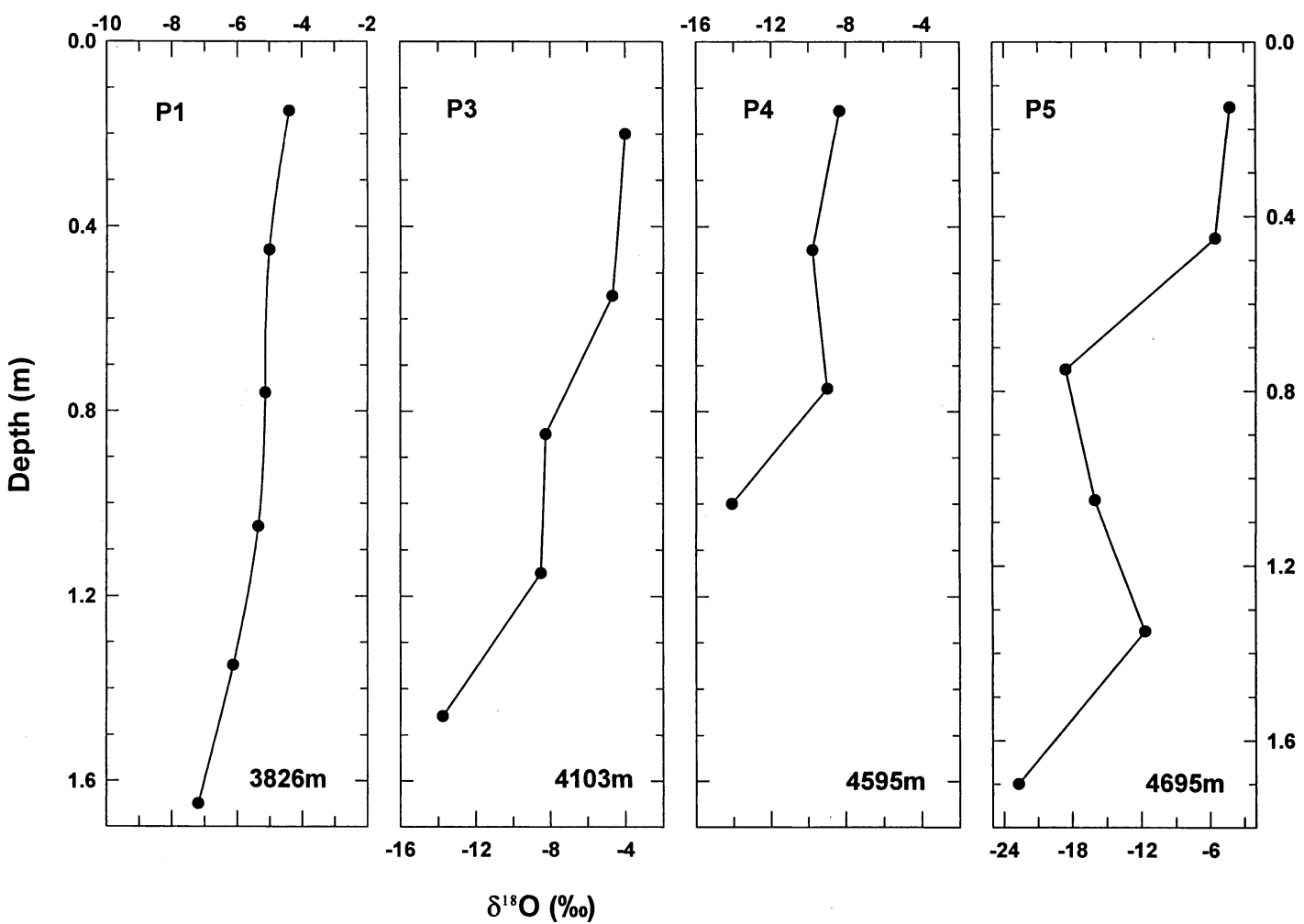

Fig. 4.Variation of $\delta^{18} O$ in snow samples with depth in four pits (P1, P3, P4 and P5) collected at different altitudes during fune 1994.

\section{$\delta^{18} O$ concentrations in snow pits}

The $\delta^{18} \mathrm{O}$ composition of snow samples, collected at varying depths from four pits at altitudes of 3826-4695 m, shows a large variation from $-4 \%$ to $-23 \%$ (Fig. 4). For pit Pl

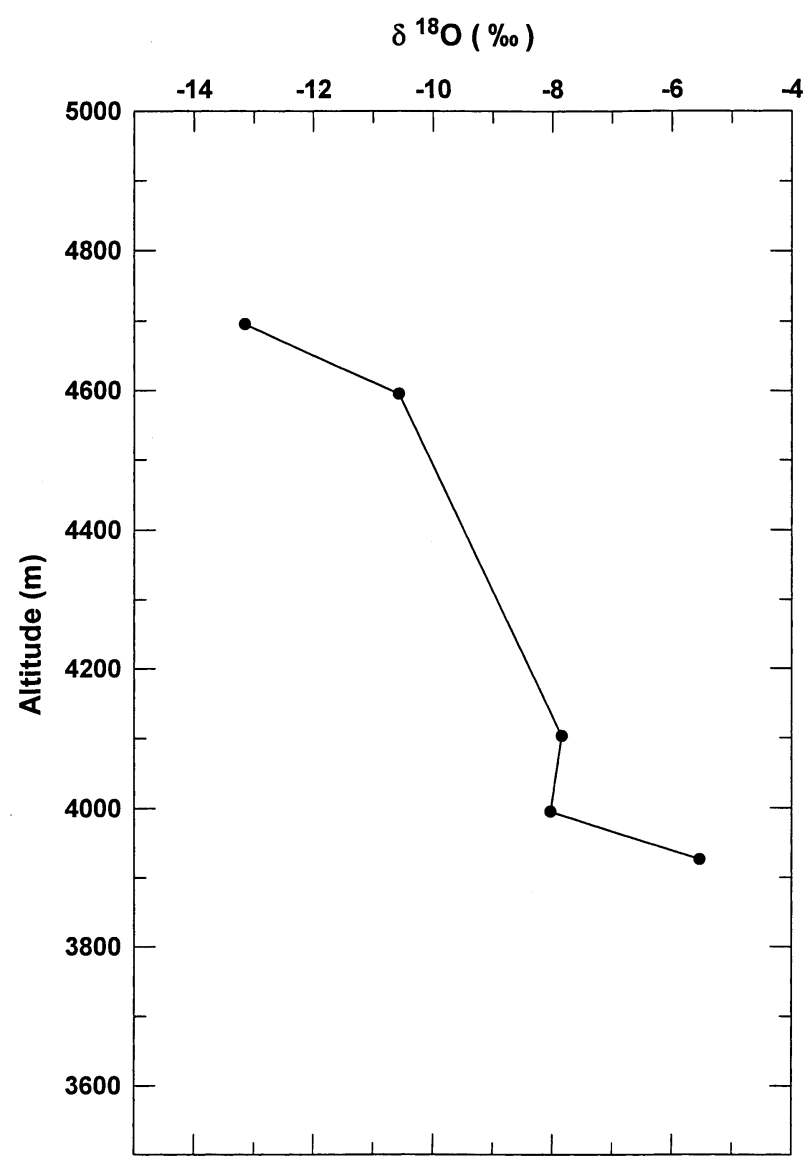

Fig. 5. The average $\delta^{18} O$ values for the individual snow pits are plotted as a function of altitude. The "altitude effect" in the oxygen isotope ratio is $0.9 \%$ per $100 \mathrm{~m}$ for DB glacier.
$(3826 \mathrm{~m}), \delta^{18} \mathrm{O}$ values range from $-4.5 \%$ to $-7.2 \%$, whereas for samples collected from pit P5 (4695 m) they range from $-5 \%$ to $-23 \%$ (Fig. 4) for the same depth range of $0-1.6 \mathrm{~m}$. A decreasing trend in $\delta^{18} \mathrm{O}$ concentrations with increasing elevation is thus observed in the snow pits (Fig. 4), with the most depleted values occurring in pit P5 from the highest elevation $(4695 \mathrm{~m})$. Snow samples within the same pit also show a seasonal variation in $\delta^{18} \mathrm{O}$ with depth (Fig. 4), suggesting that the earliest snow deposited during OctoberNovember is more depleted in $\delta^{18} \mathrm{O}$ than the snowfall during later months (February-April). The larger degree of isotopic enrichment in subsequent precipitation at successively higher elevations is attributed to the orientation of the glacier (south with respect to Himalaya, windward). These results clearly demonstrate the varying sources of moisture/ precipitation during the winter monsoon and those related to western disturbances moving over the central Himalaya. The "altitude effect" for the annual mean $\delta^{18} \mathrm{O}$ in snow is $0.9 \%$ per $100 \mathrm{~m}$ (Fig. 5) for this glacier.

The radiometric age of 400 years for snout ice, associated with a $\delta^{18} \mathrm{O}$ value of $-13.4 \%$ and mean $\delta^{18} \mathrm{O}(-9.2 \%$ o) in a $6 \mathrm{~m}$ ice core, yields a difference of $4.2 \%$, suggesting that air temperatures in this region during the LIA were cooler by at least a few ${ }^{\circ} \mathrm{C}$. The empirical relationship between $\delta^{18} \mathrm{O}$ in annual precipitation and the mean surface air temperature (at the sample location sites) for the polar regions has been established by earlier workers (Dansgaard, 1964). However, in this study it has not been possible to establish a $\delta^{18} \mathrm{O}-T$ relation, due to lack of data on mean surface air temperatures.

$\delta^{18} O$ concentrations in shallow ice core

The $\delta^{18} \mathrm{O}$ measurements on samples from a $6 \mathrm{~m}$ ice core, from the accumulation zone of the glacier, show a highly depleted value of $-15.2 \%$ at $0.25 \mathrm{~m}$ depth (Fig. 6). A likely explanation for this extreme negative value is isotopic variance and enrichment in the $\delta^{18} \mathrm{O}$ values at greater depths 
$\delta^{18} \mathrm{O}(\%)$

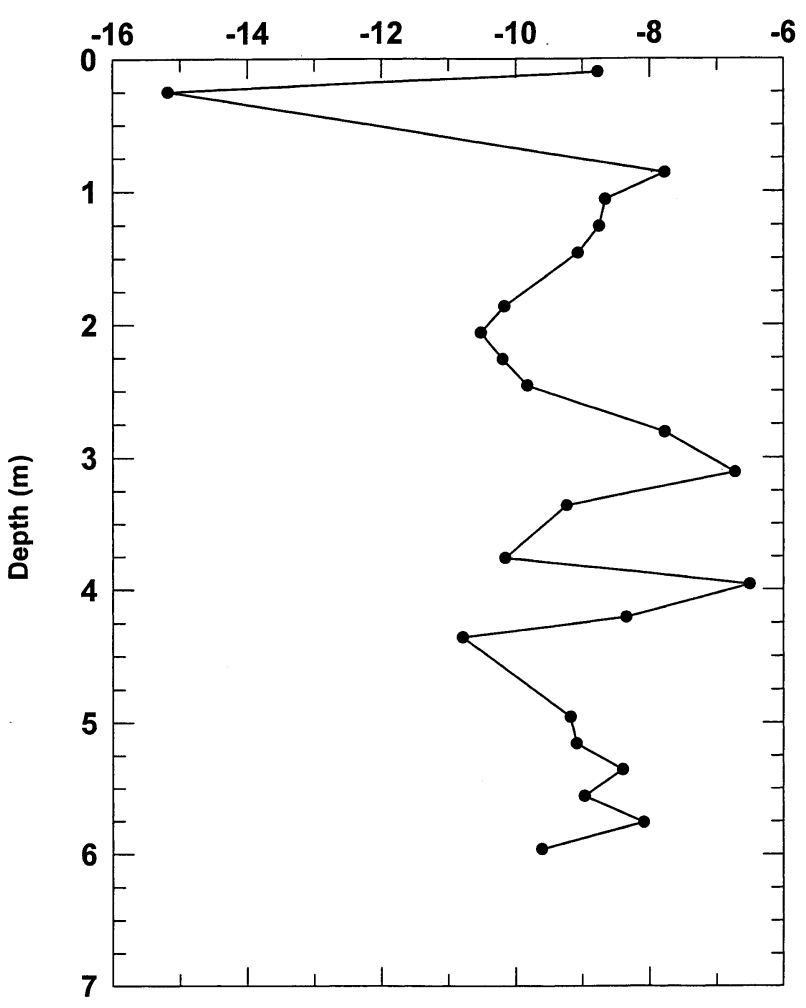

Fig. 6. Depth profile of $\delta^{18} \mathrm{O}$ values is shown in a $6 \mathrm{~m}$ ice core from an altitude of $4863 \mathrm{~m}$ in the accumulation zone. The significance of the extreme low value of $-15.2 \%$ at $0.25 \mathrm{~m}$ depth is discussed in the text.

that may have been modified via repeated freezing and thawing; and that there has not been enough time for these processes to smooth the isotopic signal in the near-surface ice. In addition, the highly depleted $\delta^{18} \mathrm{O}$ value could be associated with the episodic stormy conditions and the dominance of one of the varying sources of moisture.

\section{CONCLUSIONS}

The main conclusions that can be drawn from our study are:

1. Based on the ${ }^{137} \mathrm{Cs}$ activity in a surface ice sample collected at $4380 \mathrm{~m}$ altitude, the flow rate (ice transfer) of surface ice is estimated to be $32 \mathrm{~m} \mathrm{a}^{-1}$ near the equilibrium line. This is in contrast to the time-averaged flow rate of $14 \mathrm{ma}^{-1}$, along the entire glacier length, during the past four centuries.

2. The peak concentrations of ${ }^{137} \mathrm{Cs}\left(19.2 \mathrm{mBq} \mathrm{kg}^{-1}\right)$ observed at $3 \mathrm{~m}$ depth in an ice core confirm the presence of Chernobyl fallout activity, based on which the accumulation rate of snow at $\sim 4900 \mathrm{~m}$ altitude is calculated to be 0.43 $\mathrm{ma}^{-1}$.

3. An "altitudinal effect" of $0.9 \%$ in $\delta^{18} \mathrm{O}$ per $100 \mathrm{~m}$ elevation on DB glacier is observable in the annual snowfall.

4. A significantly depleted $\delta^{18} \mathrm{O}$ value $(-13.4 \%)$ in the snout ice compared to the mean $\delta^{18} \mathrm{O}(-9.2 \%)$ value in a shallow ice core suggests that climatic conditions during the LIA period were a few ${ }^{\circ} \mathrm{C}$ cooler than the present-day environment.

\section{ACKNOWLEDGEMENTS}

This study was funded by the Department of Science and Technology, New Delhi. We thank S. S. Das and K. Soni and members of the ice-core drilling team for their help in the field, H. B. Clausen, of the Geophysical Institute of Copenhagen for providing $\delta^{18} \mathrm{O}$ measurements in the snow/ice and ice-core samples, and S. Krishnaswami for help and encouragement during the course of this study. We also benefited from the comments of two anonymous referees and of the Scientific Editor, D. A. Peel.

\section{REFERENGES}

Aizen, V., E. Aizen, J. Melack and T. Martma. 1996. Isotopic measurements of precipitation on central Asia glaciers (southeastern Tibetan, northern Himalayas, central Tien Shan). J. Geophys. Res., 101(D4), 9185-9196.

Dansgaard, W. 1964. Stable isotopes in precipitation. Tellus, 16(4), 436-468.

Dansgaard, W., S. J. Johnsen, J. Møller and C. C. Langway, Jr. 1969. One thousand centuries of climatic record from camp Century on the Greenland ice sheet. Science, 166(3903), 377-381.

Delmas, R., M. Briat and M. Legrand. 1982. Chemistry of South polar snow. 7. Geophys. Res., 87(D6), 4314-4318.

Gergan, J.T. and D. P. Dobhal. 1996. Geomorphological studies of Dokriani Bamak (glacier), Garhwal Himalaya, UP, India. In Multidisciplinary multiinstitutional glaciological expedition to Dokriani Bamak (glacier), Garhwal Himalaya, 1992-95. Vol. 1. New Delhi, Department of Science and Technology, 1-32.

Grabczak, J., J. Niewodniczanski and K. Rózanski. 1983. Isotope stratification in high mountain glaciers: examples from the Peruvian Andes and Himalaya. f. Glaciol., 29 (103), 417-424.

Jouzel, J. and 6 others. 1987. Vostok ice core: a continuous isotope temperature record over the last climatic cycle (160,000 years). Nature, 329 (6138), 403-408.

Mayewski, P. A., W. B. Lyons, M. J. Spencer and J. L. Clayton. 1986. Correspondence. Snow chemistry from Xixabangma Peak, Tibet. f. Glaciol., 32(112), 542-543.

Nijampurkar, V. N. and N. Bhandari. 1984. Oxygen isotope ratios of some Himalayan glaciers. Tellus, 36B(4), 300-302.

Nijampurkar, V. N. and D. K. Rao. 1990. Evidence of Chernobyl fallout on a temperate Himalayan glacier. Current Sci., 59(23), 1239-1241.

Nijampurkar, V. N. and D. K. Rao. 1992. Accumulation and flow rates of ice on Chhota Shigri glacier, central Himalaya, using radio-active and stable isotopes. F. Glaciol., 38(128), 43-50.

Nijampurkar, V. N. and D. K. Rao. 1993. Ice dynamics and climatic studies on Himalayan glaciers based on stable and radioactive isotopes. International Association of Hydrological Sciences Publication 218 (Symposium at Kathmandu 1992 - Snow and Glacier Hydrology), 355-369.

Nijampurkar, V. N., N. Bhandari, C. P. Vohra and V. Krishnan. 1982. Radiometric chronology of Neh-nar Glacier, Kashmir. f. Glaciol., 28(98), 91-105.

Nijampurkar, V. N., D. K. Rao, F. Oldfield and I. Renberg. 1998. The halflife of ${ }^{32} \mathrm{Si}$ : a new estimate based on varved lake sediments. Earth Planet. Sci. Lett., 163(1-4), 191-196.

Peel, D. A., R. Mulvaney and B. M. Davison. 1988. Stable-isotope/airtemperature relationships in ice cores from Dolleman Island and the Palmer Land plateau, Antarctic Peninsula. Ann. Glaciol., 10, 130-136.

Sarin, M. M., R. Bhusan, R. Rengarajan and D. N. Yadav. 1992. Simultaneous determination of ${ }^{238} \mathrm{U}$ series nuclides in waters of Arabian Sea and Bay of Bengal. Indian F. Mar. Sci., 21, 121-127.

Thompson, L. G. and 9 others. 1997. Tropical climate instability: the last glacial cycle from a Qinghai-Tibetan ice core. Science, 276(5320), 1821-1825.

Von Gunten, H. R., E. Rössler and H. Gäggeler. 1983. Dating of ice cores from Vernagtferner (Austria) with fission products and lead-210. Z . Gletscherkd. Glazialgeol., 18(1), 1982, 37-45.

Wake, C. P. 1989. Glaciochemical investigations as a tool for determining the spatial and seasonal variation of snow accumulation in the central Karakorum, northern Pakistan. Ann. Glaciol., 13, 279-284.

Yao Tandong, L. G. Thompson, E. Mosley-Thompson, Yang Zhihong, Zhang Xinping and Lin Ping-Nan. 1996. Climatological significance of $\delta^{18} \mathrm{O}$ in north Tibetan ice cores. 7. Geophys. Res., 101 (D23), 29,531-29,538.

Yasunari, T. 1976. Spectral analysis of monsoon precipitation in Nepal Himalayas. Seppyo, 38, 59-66. 